CLINICAL STUDY

\title{
Supplementation with cholecalciferol does not result in weight reduction in overweight and obese subjects
}

\author{
$\mathrm{M} \mathrm{Sneve}^{1}$, Y Figenschau ${ }^{2,3}$ and R Jorde $\mathrm{e}^{1,4}$ \\ Departments of ${ }^{1}$ Internal Medicine and ${ }^{2}$ Medical Biochemistry, University Hospital of North Norway, 9038 Tromsø, Norway, ${ }^{3}$ Institute of Medical \\ Biology and ${ }^{4}$ Institute of Clinical Medicine, University of Tromsø, 9037 Tromsø, Norway \\ (Correspondence should be addressed to M Sneve who is now at Medical Department B, University Hospital of North Norway, PO Box 101, 9038 Tromse, \\ Norway; Email: monica.sneve@unn.no)
}

\begin{abstract}
Objective: Investigate whether cholecalciferol supplementation leads to weight loss in overweight and obese adults.

Design: Randomized double blind clinical trial with 20000 IU cholecalciferol twice a week, or $20000 \mathrm{IU}$ once a week plus placebo, or placebo twice a week, for 12 months. All subjects were given $500 \mathrm{mg}$ calcium supplementation.

Methods: Four hundred and forty five healthy, overweight, and obese men and women (age 21-70 years, body mass index (BMI) $28.0-47.0 \mathrm{~kg} / \mathrm{m}^{2}$ ). Body weight, fatness, and fat distribution parameters were measured by dual-energy X-ray absorptiometry and anthropometry, blood samples and 24-h urinary samples were collected.

Results: At baseline, there were no significant differences between the groups, but there was a significant inverse relation between serum 25-hydroxyvitamin D (25(OH)D) levels and BMI, and a significant positive association between calorie intake and BMI. Three hundred and thirty four subjects completed the study. During the study, there was no significant change in weight, waist-to-hip ratio (WHR) or percentage body fat in any of the groups, nor between them. Parathyroid hormone decreased and 25(OH)D increased significantly in both groups receiving cholecalciferol, and serum levels of $25(\mathrm{OH}) \mathrm{D}$ stabilized after 3 months. Serum calcium was unchanged in all groups. Urinary calcium excretion increased in all groups, but there was no significant difference between the groups. Weekly dosage of 20 000-40 000 IU cholecalciferol for 12 months was associated with a low risk of adverse effects, at least in overweight and obese adults living at latitude $70^{\circ} \mathrm{N}$.

Conclusion: Significant weight reduction in overweight and obese subjects is unlikely to occur with cholecalciferol supplementation.
\end{abstract}

European Journal of Endocrinology 159 675-684

\section{Introduction}

There is an increase in body weight world wide (1). The cause of obesity appears to be both genetic and environmental (2), and obesity increases the risk of several endocrine dysfunctions (3), including changes in the calcitropic hormones (4).

The importance of vitamin $\mathrm{D}$ for skeletal health is undisputed, and lack of vitamin D in childhood causes rickets. Recently, a low serum level of vitamin D has also been associated with a number of other diseases, such as inflammatory bowel disease, rheumatoid arthritis, hypertension, cardiovascular disease, diabetes mellitus, and cancer (5). There are also indications for an association between vitamin $\mathrm{D}$ and obesity, and that serum levels of 25-hydroxyvitamin D $(25(\mathrm{OH}) \mathrm{D})$ are reduced in obese subjects $(4,6,7)$. The intake of vitamin $\mathrm{D}$ is lower in obese than normal weight subjects, as we reported in an epidemiological study on more than 18000 subjects
(8). In that cohort, we found in both genders a difference in body mass index (BMI) of $\sim 1 \mathrm{~kg} / \mathrm{m}^{2}$ between those in the highest and those in the lowest quartile for vitamin $\mathrm{D}$ intake (8).

One of the consequences of a low $25(\mathrm{OH}) \mathrm{D}$ level is secondary hyperparathyroidism (9), and as a group, obese subjects have increased serum parathyroid hormone (PTH) levels (10). In isolated adipocytes, it has been demonstrated that PTH increases the cytosolic calcium level (11), which may impede the catecholamine-induced lipolysis (12) and also promote expression of fatty acid synthase (13). This would lead to accumulation of fat, and accordingly, it has been hypothesized that PTH and vitamin D may be of importance for the development of obesity (14). However, there are so far few clinical trials to support this.

The present study was undertaken to test the hypothesis that supplementation with vitamin $\mathrm{D}$ in the form of cholecalciferol would lead to weight loss in 
overweight and obese subjects. As there is an increasing consensus that the present recommendations for intake of vitamin D are too low (15), and that the optimal serum concentrations for vitamin $\mathrm{D}$ remains to be determined (16), both 20000 and 40000 IU cholecalciferol per week were compared versus placebo. In addition, all subjects received calcium supplementation as it has been reported that, at least regarding effects on glucose metabolism, this is essential for optimal effect of vitamin D (17).

\section{Subjects and methods}

\section{Subjects}

The subjects were recruited by advertisements in local newspapers and from our outpatient clinic. The subjects were initially screened at our outpatient clinic at the Department of Internal Medicine at the University Hospital of North Norway. All potential participants were told that they would be part of a weight loss study assessing the effect of high doses of vitamin D on body weight. Males and females, 21-70 years old, with BMI between 28.0 and $47.0 \mathrm{~kg} / \mathrm{m}^{2}$ were included. Subjects with diabetes or a history of coronary infarction, angina pectoris, stroke, renal stone disease, or sarcoidosis were excluded. Subjects with a weight loss of more than $10 \%$ of total body weight during the last 6 months, those using anti-depressant drugs or weight reducing drugs, those participating in an organized weight loss program, pregnant or lactating women, women planning to become pregnant in the next 12 months, women below the age of 50 years without adequate contraception (contraceptive pills, implantable subdermal contraceptive rods, contraceptive dermal patches, injectable contraceptives, vaginal contraceptive rings, or intrauterine devices, with pearl index $<1.0$ ), subjects with serum calcium $>2.55 \mathrm{mmol} / \mathrm{l}$, males with serum creatinine $>129 \mu \mathrm{mol} / \mathrm{l}$, and females with serum creatinine $>104 \mu \mathrm{mol} / \mathrm{l}$ were not included. If the serum calcium was in the range $2.50-2.55 \mathrm{mmol} / \mathrm{l}$, serum PTH had to be below $5.0 \mathrm{pmol} / \mathrm{l}$.

\section{Protocol}

Non-fasting blood samples for determination of plasma PTH, serum calcium, and creatinine were drawn. If the inclusion criteria were met, the next visit (baseline) was performed in the fasting state within 2 weeks at the Hospital's Clinical Research Unit. An oral glucose tolerance test was performed to exclude subjects with undiagnosed diabetes, and blood samples for determination of fasting serum PTH were drawn. At this visit, any previous supplements with calcium and vitamin D (including cod liver oil) were discontinued and all subjects were given a daily supplement with $500 \mathrm{mg}$ calcium (Nycoplus Calcium, Nycomed, Oslo, Norway)) throughout the 1-year intervention period. The participants were given written recommendations on healthy diet and physical activity. The subjects were randomized into three groups, stratified by gender and smoking status: group DD was to take two capsules of vitamin D (20 000 IU cholecalciferol per capsule (Decristol, Jenapharm, Jena, Germany) per week; group DP one capsule of vitamin D and one placebo capsule per week; and group PP two placebo capsules per week. The placebo capsules, purchased from Hasco-lek, Wroclaw, Poland, were identical to the vitamin D capsules. The subjects were instructed to take one capsule each Monday from the 'Monday box' and one capsule each Thursday from the 'Thursday box'. If they missed a capsule on the assigned day, it could be taken another day. If a whole week was missed, double dose could be taken the next week. The subjects were supplied with new medication every third month (one box with 100 calcium tablets, one 'Monday box' with 15 capsules and one 'Thursday box' with 15 capsules (placebo or vitamin D)). The unused calcium tablets and capsules were returned and counted. For the calculation of the compliance rate, those that did not return the boxes with unused medication for counting were considered not to have taken any of that medication during that period. The compliance rate for those who had taken more than prescribed during the 12 months was set to $100 \%$. Adverse events were registered every third month. The subjects were classified as current smokers or current non-smokers.

The study was a randomized double blind clinical trial; neither the data collectors nor the laboratory staff knew the randomized group status of the participants.

\section{Power calculation}

In the power calculation, we used for body weight a S.D. of $11.9 \mathrm{~kg}$ based on data from the fifth Tromsø Study for subjects with BMI in the range $30-40 \mathrm{~kg} / \mathrm{m}^{2}(10)$, and a clinically relevant difference of $6 \mathrm{~kg}$ with or without vitamin D. Thus, if 450 subjects were included and 120 in each group completed the study, we would have a $92 \%$ chance of finding a difference between the three groups. This power analysis was performed with a $P<0.01$ to account for multiple comparisons because of more than two subgroups.

\section{Measurements}

Height, weight, and waist and hip circumference were measured every third month, wearing light clothing and no shoes.

Total body fat was measured with dual-energy X-ray absorptiometry according to the manufacturer (GE Lunar Prodigy, LUNAR Corporation, Madison, WI, USA) at baseline and at the end of the study. The percentage total body fat was calculated by dividing the total fat mass by body weight and multiplying by one hundred.

A food-frequency questionnaire (18) and a questionnaire on physical activity (International Physical Activity 
Questionnaire, short last 7 days self-administered format) (19) were filled in at baseline and at the end of the study. The intakes of calories, vitamin $\mathrm{D}$, and calcium were calculated (18). The amount of physical activity was calculated based on reported vigorous, moderate, and walking activities and given in units of metabolic equivalents (MET)-min/week, where METs are multiples of the resting metabolic rate.

Non-fasting blood samples for serum calcium analysis were drawn after 3, 6, and 9 months to disclose development of hypercalcemia. At the end of the study after 12 months, fasting blood samples, including serum PTH, were analyzed. Serum samples for determination of $25(\mathrm{OH}) \mathrm{D}$ were drawn at all visits. If serum calcium increased $>2.59 \mathrm{mmol} / \mathrm{l}$, the subjects were asked to take a second test and, if still $>2.59 \mathrm{mmol} / \mathrm{l}$, they were excluded from the study. Urine for measurement of calcium excretion was collected for $24 \mathrm{~h}$ at baseline and at the end of the study.

Serum calcium and creatinine, and plasma PTH at the screening visit were measured consecutively, whereas fasting serum PTH from baseline and after 12 months were analyzed in a batch at the end of the study, as were the serum $25(\mathrm{OH}) \mathrm{D}$ samples. Serum calcium, creatinine, and PTH were measured as previously described (9). Reference ranges in our laboratory at the time of the study were for serum calcium 2.20-2.60 mmol/l; for serum PTH, 1.1-6.8 pmol/l for those 50 years old and younger, and $1.1-7.5 \mathrm{pmol} / \mathrm{l}$ for those older than 50 years; for serum creatinine 70-120 $\mu \mathrm{mol} / \mathrm{l}$ for men and 55-100 $\mu \mathrm{mol} / \mathrm{l}$ for women. Serum $25(\mathrm{OH}) \mathrm{D}_{3}$ was determined by immunometry (electrochemiluminescence: ECLIA), using an automated clinical chemistry analyser (Modular E170, Roche Diagnostics). According to the producer, the assay has, for total analytical precision, a coefficient of variation $\leq 7.8 \%$ as judged in any of three different concentrations $(48.6-73.8-177.0 \mathrm{nmol} / \mathrm{l})$. The crossreactivity with $25(\mathrm{OH}) \mathrm{D}_{2}$ was $<10 \%$ and the analytical sensitivity was $10 \mathrm{nmol} / \mathrm{l}$. At present, the laboratory has no reference values for $25(\mathrm{OH}) \mathrm{D}_{3}$, but the manufacturer provides a population-based reference range of 27.7-107.0 nmol/l for adults as a guideline. Urinary calcium was measured on a Modular P800 (Roche Diagnostics), with reagents from the same company. The reference range for urinary calcium was $2.0-8.0 \mathrm{mmol} / 24 \mathrm{~h}$. The trial was registered at Clinical Trials.gov (NCT00243256).

\section{Statistical analyses}

Normal distribution was evaluated with visual inspection of histograms with normal curve, normality plots (Q-Q-plots), and determination of skewness and kurtosis. The dependent variables were considered normally distributed.

Correlations were evaluated with Pearson's correlation coefficient $r$. Individual predictors of BMI were evaluated with linear regression with covariates as appears in Table 2. Comparisons between groups were done by Student's $t$-test, applying Bonferroni correction for multiple analyses.

In addition, a linear mixed model with a Toeplitz covariance structure to adjust for dependency between the repeated measures of weight, hip circumference, waist circumference, WHR, and BMI as dependent variables respectively was used in order to incorporate all the repeated measures. As predictor variables of interest, time was included as a continuous linear variable and the treatment groups were included as two indicator variables, and analyses were done both unadjusted and adjusted for age and sex. In order to assess different time trends between the treatment groups, two-way interaction terms between time and the indicator variables of treatment groups were added. In order to assess whether a possible difference in time trends between the treatment groups varies between men and women, or by age, three-way interaction terms between time, the indicator variables of treatment groups, and sex or age were added.

Unless otherwise stated, data are expressed as mean \pm S.D. All tests were done two sided, and $P$ value $<0.05$ was considered statistically significant. The Statistical Package for Social Sciences version 14.0 was used for all statistical analyses (SPSS Inc., Chicago, IL, USA).

\section{Ethics}

The study was approved by the Regional Ethics Committee. All participants gave written informed consent prior to the study.

\section{Results}

Of a total of 496 screened subjects, 445 met the inclusion criteria. Figure 1 displays a flow chart of the study population. The inclusion period started in November 2005 and the last person was included in October 2006. Their baseline characteristics are shown in Table 1. There were no significant differences between the three treatment groups at baseline. There was a significant inverse association between serum $25(\mathrm{OH}) \mathrm{D}$ and $\mathrm{BMI}$, and a significant positive association between calorie intake and BMI (Table 2).

Three hundred and thirty four subjects completed the study. Table 3 shows when, and for what reason, subjects withdrew their consent or were excluded from the study. During the 1-year period, there was no significant change in weight in any of the three groups or between these groups (Tables 1 and 4). The same was seen when dividing the cohort according to baseline serum 25(OH)D levels (Table 5). Similarly, there were no differences from baseline or between the groups regarding WHR or percentage body fat at the end of the study (Table 1). Using a repeated measures 


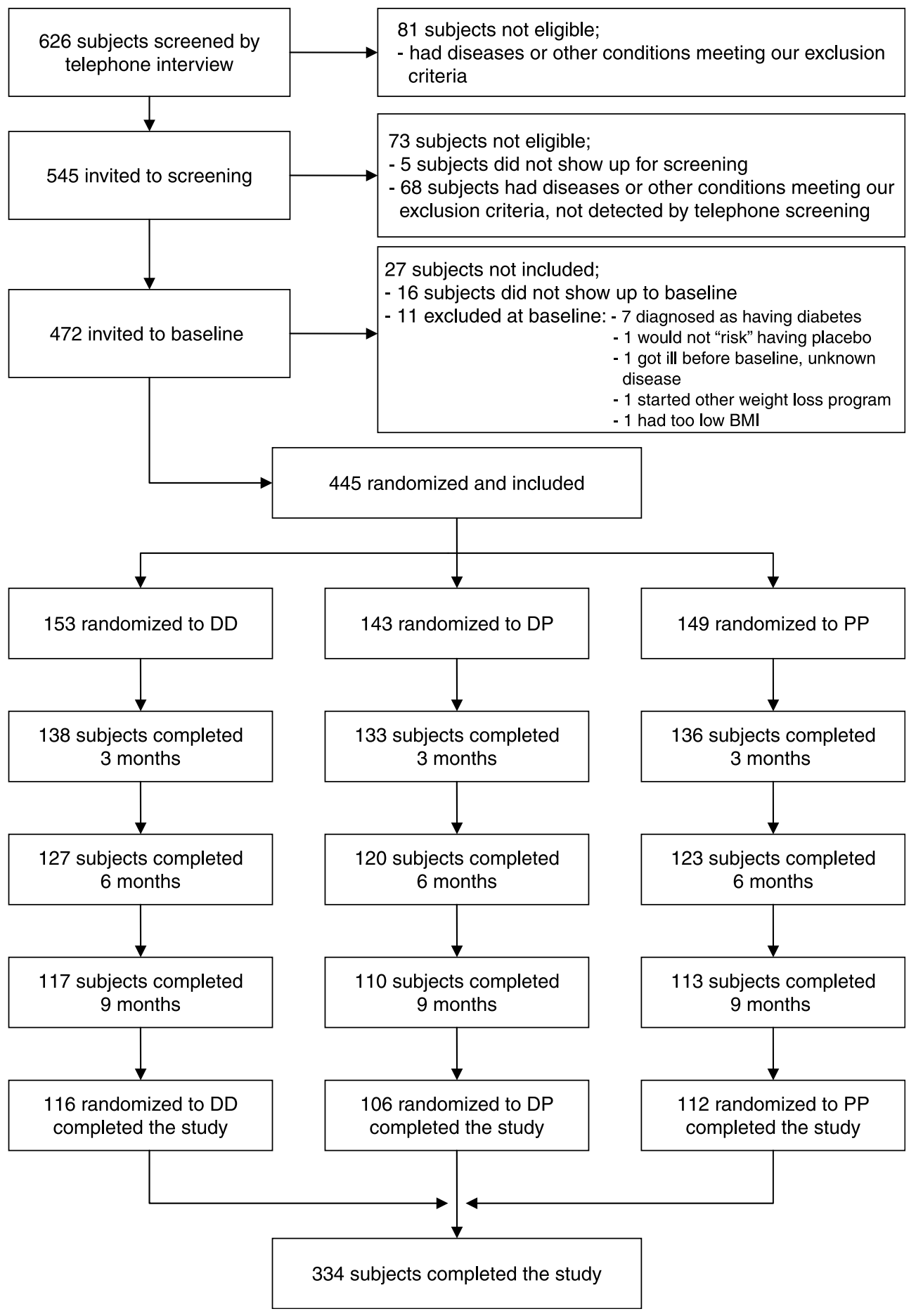

Figure 1 Flow chart of the study population during the study period (DD =calcium $500 \mathrm{mg} /$ day + cholecalciferol $40000 \mathrm{IU} / \mathrm{week}$; $\mathrm{DP}=$ calcium $500 \mathrm{mg} /$ day + cholecalciferol $20000 \mathrm{lU} /$ week; PP = calcium $500 \mathrm{mg} /$ day + placebo).

analysis, there was no significant difference in time trend between the groups neither in body weight, BMI, waist circumference, hip circumference nor WHR (data not shown). Nor were there any differences in the effect of the intervention by sex or age (data not shown).
To explore the possible effect of time of year at inclusion, the subjects were divided in those included from April to September (the 'summer season') and those included from October to March (the 'winter season'). Looking at all subjects together, those included during the 'summer 
Table 1 Baseline characteristics of the study population and change from baseline at the end of the study.

\begin{tabular}{|c|c|c|c|c|c|c|c|}
\hline & \multicolumn{4}{|c|}{ Baseline characteristics } & \multicolumn{3}{|c|}{$\begin{array}{l}\text { Gender, age, and change from baseline }{ }^{a} \text { in } \\
\text { the } 334 \text { subjects who completed the study }\end{array}$} \\
\hline & All subjects & DD group ${ }^{b}$ & DP group ${ }^{c}$ & PP group ${ }^{d}$ & DD group ${ }^{b}$ & DP group ${ }^{c}$ & PP group ${ }^{d}$ \\
\hline Males/females & 159/286 & $57 / 96$ & $51 / 92$ & $51 / 98$ & $47 / 69$ & $40 / 66$ & $41 / 71$ \\
\hline Age (years) & $47.6 \pm 11.4$ & $46.4 \pm 11.3$ & $47.6 \pm 11.9$ & $48.9 \pm 11.0$ & $47.7 \pm 11.1^{*}$ & $48.8 \pm 11.8$ & $51.2 \pm 10.6$ \\
\hline Weight $(\mathrm{kg})$ & $100.1 \pm 14.2$ & $101.0 \pm 14.5$ & $98.6 \pm 14.3$ & $100.6 \pm 13.9$ & $0.1 \pm 3.8$ & $0.3 \pm 3.2$ & $0.5 \pm 3.9$ \\
\hline BMI $\left(\mathrm{kg} / \mathrm{m}^{2}\right)$ & $34.8 \pm 3.9$ & $35.0 \pm 4.1$ & $34.4 \pm 3.9$ & $35.1 \pm 3.8$ & $0.0 \pm 1.3$ & $0.1 \pm 1.1$ & $0.2 \pm 1.4$ \\
\hline Waist hip ratio & $0.97 \pm 0.09$ & $0.97 \pm 0.09$ & $0.96 \pm 0.09$ & $0.97 \pm 0.08$ & $-0.01 \pm 0.05$ & $-0.01 \pm 0.04$ & $-0.01 \pm 0.05$ \\
\hline Body fat (\%) & $43.0 \pm 7.5$ & $42.9 \pm 7.9$ & $42.9 \pm 7.6$ & $43.1 \pm 6.9$ & $-0.3 \pm 2.1$ & $-0.4 \pm 1.9$ & $-0.5 \pm 2.1$ \\
\hline Serum calcium $(\mathrm{mmol} / \mathrm{l})$ & $2.31 \pm 0.11$ & $2.31 \pm 0.11$ & $2.32 \pm 0.11$ & $2.31 \pm 0.10$ & $0.00 \pm 0.12$ & $-0.01 \pm 0.11$ & $-0.01 \pm 0.11$ \\
\hline Serum PTH (pmol/l) & $5.40 \pm 1.87$ & $5.20 \pm 1.58$ & $5.36 \pm 1.78$ & $5.65 \pm 2.19$ & $-0.92 \pm 1.51^{\star}$ & $-0.80 \pm 1.44^{*}$ & $-0.26 \pm 1.59$ \\
\hline Serum 25(OH)D (nmol/l) & $53.1 \pm 16.9$ & $54.5 \pm 16.7$ & $51.4 \pm 18.4$ & $53.2 \pm 15.4$ & $59.8 \pm 21.1^{*}$ & $37.8 \pm 15.7^{*}$ & $-2.3 \pm 9.5$ \\
\hline Urinary calcium (mmol/day) & $4.92 \pm 2.65$ & $5.19 \pm 2.68$ & $4.92 \pm 2.68$ & $4.65 \pm 2.56$ & $1.14 \pm 2.25$ & $0.77 \pm 2.35$ & $0.78 \pm 2.24$ \\
\hline Calorie intake (J/day) & $9161 \pm 2887$ & $9166 \pm 2986$ & $9044 \pm 2933$ & $9265 \pm 2752$ & $-221 \pm 2070$ & $-480 \pm 2372$ & $-566 \pm 1687$ \\
\hline Calcium intake (mg/day) & $940 \pm 398$ & $922 \pm 368$ & $943 \pm 438$ & $955 \pm 390$ & $360 \pm 316^{\mathrm{e}}$ & $362 \pm 370^{e}$ & $335 \pm 338^{\mathrm{e}}$ \\
\hline Vitamin D intake ( $\mu \mathrm{g} /$ day) & $8.9 \pm 6.6$ & $9.0 \pm 6.7$ & $9.1 \pm 7.0$ & $8.9 \pm 6.2$ & $-1.6 \pm 6.5$ & $-1.2 \pm 6.9$ & $-0.8 \pm 5.7$ \\
\hline $\begin{array}{l}\text { Physical activity score } \\
\text { (MET-min/week) }\end{array}$ & $3410 \pm 3860$ & $3749 \pm 4439$ & $3191 \pm 3859$ & $3282 \pm 3184$ & $-323 \pm 3807$ & $301 \pm 3891$ & $-370 \pm 3102$ \\
\hline Smokers (\%) & 22.0 & 22.9 & 21.7 & 21.5 & -4.3 & -2.9 & -2.7 \\
\hline
\end{tabular}

${ }^{*} P<0.05$ versus PP group, Student's $t$-test.

avalue at 12 months minus value at baseline.

${ }^{\mathrm{b} C}$ Calcium $500 \mathrm{mg} /$ day + cholecalciferol $40000 \mathrm{IU} /$ week.

${ }^{c}$ Calcium $500 \mathrm{mg} /$ day + cholecalciferol $20000 \mathrm{IU} /$ week.

${ }^{\mathrm{d}}$ Calcium $500 \mathrm{mg} /$ day + placebo.

${ }^{\mathrm{e}}$ Including calcium supplementation taken as study medication, adjusted for individual compliance rate.

season' had a mean weight loss of $0.2 \pm 3.4 \mathrm{~kg}$, whereas those included during the 'winter season' had a mean weight gain of $0.7 \pm 3.8 \mathrm{~kg}(P<0.05)$. Looking at the three treatment groups separately, there was a significant seasonal difference in weight change within the DD-group only, where those included during the 'summer season' had a mean weight loss of $0.9 \pm 3.7 \mathrm{~kg}$, whereas those included during the 'winter season' had a mean weight gain of $1.0 \pm 3.6 \mathrm{~kg} \quad(P<0.05)$. However, when comparing the weight changes between the three groups, there were no statistically significant differences neither in the 'summer' nor the 'winter' cohorts.

There was a significant increase in serum 25(OH)D in the DD and DP groups, and their serum levels were stable from 3 months until the end of the study (Fig. 2). The increase in serum $25(\mathrm{OH}) \mathrm{D}$ was significant at all time points between the active groups and placebo, and also between the DD and DP groups (Fig. 2). Serum PTH decreased significantly in the DD and DP groups (Table 1), whereas serum calcium was unchanged in all three groups. There was an increase in urinary calcium excretion in all groups at the end of the study, but there was no significant difference between the groups.

The compliance rate for cholecalciferol/placebo capsules were $95 \%$ in all three groups, and for the calcium tablets 81,85 , and $83 \%$ in the DD, DP, and PP groups respectively.

\section{Adverse events and withdrawal from the study}

Two subjects were diagnosed as having primary hyperparathyroidism (PHPT) during the study, and one had an increase in serum calcium to $2.62 \mathrm{mmol} / \mathrm{l}$, and hence all three were excluded from the study. Four subjects had transient increases in serum calcium $>2.59 \mathrm{mmol} / \mathrm{l}$ and remained in the study. Details about these 7 subjects are given in Table 6 . In addition, 317 other adverse events were recorded, most of them related to gastro-intestinal discomfort. There were no significant differences between the treatment groups regarding adverse events (Table 7).

Table 2 Predictors of body mass index (BMI) in the 445 subjects at baseline evaluated by Pearson correlation coefficient $r$ and in a multiple linear regression model with the standardized $\beta$-coefficient $(\beta)$.

\begin{tabular}{|c|c|c|c|}
\hline \multirow[b]{2}{*}{ Independent variables } & \multicolumn{3}{|c|}{ BMI as dependent variable } \\
\hline & $r$ & $\beta$ & $\begin{array}{l}P \text { (linear } \\
\text { regression) }\end{array}$ \\
\hline Age (years) & $-0.16^{\dagger}$ & -0.07 & NS \\
\hline Gender $($ males $=1$, females $=2)$ & & 0.10 & $<0.05$ \\
\hline Serum calcium $(\mathrm{mmol} / \mathrm{l})$ & 0.02 & 0.08 & NS \\
\hline Serum PTH $(\mathrm{pmol} / \mathrm{l})$ & $0.10^{*}$ & 0.09 & NS \\
\hline Serum 25(OH)D (nmol/l) & $-0.25^{\dagger}$ & -0.22 & $<0.001$ \\
\hline Calorie intake (J/day) & $0.14^{\dagger}$ & 0.20 & $<0.01$ \\
\hline Calcium intake (mg/day) & 0.06 & -0.06 & NS \\
\hline Vitamin D intake ( $\mu \mathrm{g} / \mathrm{day}$ ) & -0.06 & -0.04 & NS \\
\hline $\begin{array}{l}\text { Smoking }(\text { smokers }=1 \\
\text { non-smokers }=2 \text { ) }\end{array}$ & & -0.09 & NS \\
\hline $\begin{array}{l}\text { Physical activity score } \\
\text { (MET-min/week) }\end{array}$ & -0.09 & -0.09 & NS \\
\hline$R^{2}$ & & 0.12 & \\
\hline
\end{tabular}

${ }^{\star} P<0.05 ;{ }^{\dagger} P<0.01$, Pearson correlation. NS, non-significant. 
Table 3 Overview of number of subjects $(M)$ who were excluded or who withdrew their consent during the study.

\begin{tabular}{|c|c|c|c|c|c|c|c|}
\hline \multirow{2}{*}{$\begin{array}{l}\text { Out of study } \\
\text { Time point }\end{array}$} & \multirow{2}{*}{$\begin{array}{c}N \\
\text { Total }\end{array}$} & \multicolumn{2}{|r|}{ DD group ${ }^{a}$} & \multicolumn{2}{|r|}{ DP group ${ }^{b}$} & \multicolumn{2}{|r|}{ PP group ${ }^{c}$} \\
\hline & & $N$ & Reason for exclusion or withdrawal & $N$ & Reason for exclusion or withdrawal & $N$ & Reason for exclusion or withdrawal \\
\hline Before 3 months & 38 & 15 & $\begin{array}{l}13 \text { withdrew consent, no reason } \\
1 \text { elective surgery for hernia, } \\
\text { requiring rapid weight loss }\end{array}$ & 10 & $\begin{array}{l}5 \text { withdrew consent, no reason } \\
1 \text { started other weight loss program } \\
1 \text { not willing to discontinue food } \\
\text { supplements } \\
1 \text { traumatic fracture } \\
1 \text { possible multiple sclerosis } \\
1 \text { no longer safe contraception }\end{array}$ & 13 & $\begin{array}{l}10 \text { withdrew consent, no reason } \\
1 \text { moved } \\
1 \text { non-compliant for calcium tablets } \\
1 \text { urolithiasis }\end{array}$ \\
\hline Before 6 months & 37 & 11 & $\begin{array}{l}9 \text { withdrew consent, no reason } \\
1 \text { difficult to draw blood } \\
1 \text { started antidepressant } \\
\text { pharmaco-therapy }\end{array}$ & 13 & $\begin{array}{l}8 \text { withdrew consent, no reason } \\
1 \text { gastritis } \\
1 \text { started weight reducing drug } \\
1 \text { other weight loss program } \\
1 \text { no longer safe contraception } \\
1 \text { allergic reaction, not related to } \\
\text { study medication }\end{array}$ & 13 & $\begin{array}{l}8 \text { withdrew consent, no reason } \\
1 \mathrm{PHPT} \\
1 \text { started weight-reducing drug } \\
1 \text { palpitations } \\
1 \text { moved } \\
1 \text { hypothyroidism }\end{array}$ \\
\hline Before 9 months & 30 & 10 & $\begin{array}{l}9 \text { withdrew consent, no reason } \\
1 \text { angina pectoris }\end{array}$ & 10 & $\begin{array}{l}6 \text { withdrew consent, no reason } \\
1 \text { diagnosed celiac disease } \\
1 \text { urolithiasis } \\
1 \text { PHPT } \\
1 \text { hypercalcemia, low degree }\end{array}$ & 10 & $\begin{array}{l}9 \text { withdrew consent, no reason } \\
1 \text { started weight reducing drug }\end{array}$ \\
\hline Before 12 months & 6 & 1 & 1 withdrew consent, no reason & 4 & $\begin{array}{l}3 \text { withdrew consent, no reason } \\
1 \text { angina pectoris }\end{array}$ & 1 & 1 pregnant \\
\hline Total & 111 & 37 subjects & & 37 subjects & & 37 subjects & \\
\hline
\end{tabular}

${ }^{\mathrm{a} C a l c i u m} 500 \mathrm{mg} /$ day + cholecalciferol $40000 \mathrm{IU} /$ week

${ }^{b}$ Calcium $500 \mathrm{mg} /$ day + cholecalciferol $20000 \mathrm{lU} /$ week.

${ }^{\circ}$ Calcium $500 \mathrm{mg} /$ day + placebo. 
Table 4 Body weight and number of subjects in each treatment group during the study.

\begin{tabular}{|c|c|c|c|c|c|c|}
\hline \multirow[b]{2}{*}{ Visit } & \multicolumn{2}{|c|}{ DD group ${ }^{a}$} & \multicolumn{2}{|c|}{ DP group ${ }^{b}$} & \multicolumn{2}{|c|}{ PP group ${ }^{c}$} \\
\hline & $N$ & Weight (kg) & $N$ & Weight (kg) & $N$ & Weight (kg) \\
\hline Baseline & 153 & $101.0 \pm 14.5$ & 143 & $98.6 \pm 14.3$ & 149 & $100.6 \pm 13.9$ \\
\hline 3 months & 138 & $100.3 \pm 14.5$ & 133 & $98.9 \pm 14.3$ & 136 & $101.2 \pm 14.1$ \\
\hline 6 months & 127 & $100.3 \pm 14.1$ & 120 & $97.6 \pm 14.0$ & 123 & $101.6 \pm 14.5$ \\
\hline 9 months & 117 & $100.2 \pm 14.5$ & 110 & $97.8 \pm 13.7$ & 113 & $101.1 \pm 14.0$ \\
\hline 12 months & 116 & $100.3 \pm 14.9$ & 106 & $97.8 \pm 13.3$ & 112 & $101.2 \pm 14.6$ \\
\hline
\end{tabular}

${ }^{\mathrm{a} C}$ Calcium $500 \mathrm{mg} /$ day + cholecalciferol $40000 \mathrm{IU} /$ week.

${ }^{\mathrm{b}}$ Calcium $500 \mathrm{mg} /$ day + cholecalciferol $20000 \mathrm{lU} /$ week.

${ }^{\text {CCalcium }} 500 \mathrm{mg} /$ day + placebo.

\section{Discussion}

In the present study, we have found that in overweight and obese subjects, supplementation with cholecalciferol and calcium when compared with calcium alone does not lead to significant reduction in total weight, percentage fat mass, or change in fat distribution as evaluated by the WHR.

At baseline, we found the expected inverse relation between body weight and serum levels of $25(\mathrm{OH})$ vitamin $\mathrm{D}$ and a positive relation between body weight and serum PTH. After supplementation with cholecalciferol, there was a sustained increase in serum $25(\mathrm{OH}) \mathrm{D}$ levels in both the DD and DP groups, and the levels observed were in the high physiological range. The expected reduction in serum PTH was observed, but there was no reduction in body weight, not even in those with initial low serum 25(OH)D levels.

The seasonal variation of body weight could have masked our results. However, our results were not affected by season of inclusion when Bonferroni correction was used in the analyses, thus the lack of effect of vitamin D on body weight was not a result of a masked effect of season of inclusion on body weight. If there was any effect at all, it was during warm seasons.

There are few previous studies reporting the effect of vitamin D supplementation on weight, and the results are diverging. Thus, in a study by Ljunghall et al. on 65 men aged 61-65 years, there was after 12 weeks a significant weight loss of $1.1 \mathrm{~kg}$ in the group given $0.75 \mu \mathrm{g}$ alphacalcidol when compared with the placebo group (20). Similarly, in a long-term study of 18 months, Lind et al. found alphacalcidol to cause a small but significant weight loss of $0.9 \mathrm{~kg}$ in a group of 14 middle-aged men (21). On the other hand, in a study by Nilas and Christiansen from 1984 that included a total of 238 postmenopausal women, treatment for 1 year with either $2000 \mathrm{IU}$ cholecalciferol, $0.25 \mu \mathrm{g}$ alphacalcidol, or $0.25-0.50 \mu \mathrm{g}$ calcitriol had no effect on body weight when compared with placebo (22). Furthermore, in a recent study by Trivedi et al. on men and women aged 65 years or above, cholecalciferol in a dose of $100000 \mathrm{IU}$ or placebo was given every 4 months and, in a subgroup analysis on 238 subjects, there was no significant difference in body weight between the two groups after 5 years (23). In view of the two latter studies, together with our findings, we consider it highly unlikely that supplementation with cholecalciferol has a major effect on weight. This is also supported by a recent study where supplementation with $2000 \mathrm{IU}$ cholecalciferol daily for 7 days in ten healthy young men had no effects on energy expenditure or gene expression of proteins related to fat metabolism (24).

On the other hand, in the Women's Health Initiative, where 36282 postmenopausal women aged 50-79 years were randomized to $1000 \mathrm{mg}$ of elemental calcium and $400 \mathrm{IU}$ of cholecalciferol daily for 7 years versus placebo, those in the active treatment arm had less weight gain compared with the controls (25). However, that study is not directly comparable with ours as we gave all participants calcium supplementation.

Table 5 Change in weight (weight at end of the study minus weight at baseline, $\Delta$ weight) in relation to initial level of serum $25(\mathrm{OH}) \mathrm{D}$ in each treatment group.

\begin{tabular}{|c|c|c|c|c|c|c|}
\hline \multirow[b]{2}{*}{$\begin{array}{l}\text { Serum } 25(\mathrm{OH}) \mathrm{D} \\
\text { at baseline }\end{array}$} & \multicolumn{2}{|c|}{ DD group ${ }^{a}$} & \multicolumn{2}{|c|}{ DP group ${ }^{b}$} & \multicolumn{2}{|c|}{ PP group ${ }^{c}$} \\
\hline & $N$ & $\Delta$ weight $(\mathrm{kg})$ & $N$ & $\Delta$ weight $(\mathrm{kg})$ & $N$ & $\Delta$ weight $(\mathrm{kg})$ \\
\hline$<20 \mathrm{nmol} / \mathrm{l}$ & 6 & $1.8 \pm 4.7$ & 14 & $0.9 \pm 4.3$ & 7 & $0.1 \pm 1.6$ \\
\hline$<39 \mathrm{nmol} / \mathrm{l}$ & 18 & $0.1 \pm 3.8$ & 26 & $0.9 \pm 3.3$ & 23 & $-0.1 \pm 5.1$ \\
\hline $40-59 \mathrm{nmol} / \mathrm{l}$ & 57 & $0.4 \pm 4.0$ & 42 & $-0.0 \pm 3.4$ & 50 & $0.4 \pm 4.1$ \\
\hline$>59 \mathrm{nmol} / \mathrm{l}$ & 40 & $-0.2 \pm 3.7$ & 38 & $0.3 \pm 3.0$ & 39 & $0.9 \pm 2.8$ \\
\hline
\end{tabular}

${ }^{\mathrm{a} C}$ Calcium $500 \mathrm{mg} /$ day + cholecalciferol $40000 \mathrm{lU} /$ week.

${ }^{\mathrm{b} C a l c i u m} 500 \mathrm{mg} /$ day + cholecalciferol $20000 \mathrm{lU} /$ week.

${ }^{\text {CCalcium }} 500 \mathrm{mg} / \mathrm{day}$ + placebo. 


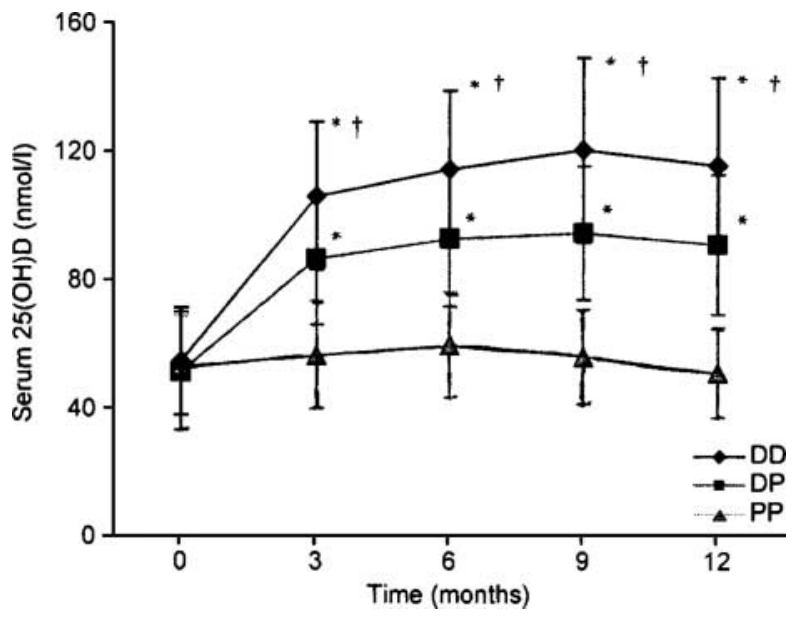

Figure 2 Mean serum levels of 25(OH)D during the study period in the three groups (error bars indicate the s.D.; ${ }^{*} P<0.001$ versus $P P$ group, ${ }^{\dagger} P<0.001$ versus DP group) ( $\mathrm{DD}=$ calcium $500 \mathrm{mg} /$ day + cholecalciferol $40000 \mathrm{IU} /$ week; DP = calcium $500 \mathrm{mg} /$ day + cholecalciferol $20000 \mathrm{IU} /$ week; PP = calcium $500 \mathrm{mg} /$ day + placebo)

From a theoretical point of view, there are several mechanisms whereby supplementation with cholecalciferol could affect weight. First, several clinical studies indicate that increasing the intake of calcium reduces the risk of overweight (26). As vitamin D causes an increase in the intestinal calcium absorption, this would augment a weight reducing effect of calcium, except for that possibly related to increased fecal fat excretion. Secondly, supplementation with cholecalciferol causes a reduction in the serum PTH level. From in vitro studies, PTH has been found to increase the intracellular calcium level (11) which in turn may induce fat accumulation (12-14). On the other hand, cholecalciferol not only increases the serum 25(OH)D levels, but due to higher substrate availability also the serum 1,25dihydroxyvitamin $\mathrm{D}\left(1,25(\mathrm{OH})_{2} \mathrm{D}\right)$ levels $(27)$. Similar to PTH, $1,25(\mathrm{OH})_{2} \mathrm{D}$ increases the intracellular calcium levels $(28,29)$ that may promote weight gain $(12-14)$. Accordingly, the resulting effect on adipocytes following calciferol supplementation would depend on the relative importance of reducing the PTH level versus increasing the $1,25(\mathrm{OH})_{2} \mathrm{D}$ level.

The optimal serum 25(OH)D level is not known, but has been estimated to be between 90 and $100 \mathrm{nmol} / \mathrm{l}(16)$, and a wider range between 75 and $100 \mathrm{nmol} / \mathrm{l}$ is considered to be normal (30). The amount of cholecalciferol needed to reach this level is probably much higher than the recommended 400-600 IU/day for adults (31) and may be even higher than $4000 \mathrm{IU} /$ day (32). We therefore decided to give two doses of vitamin D; 20000 and $40000 \mathrm{IU} /$ week to ensure that a lack of effect could not be ascribed to suboptimal serum $25(\mathrm{OH}) \mathrm{D}$ levels. Furthermore, from current knowledge, we considered this dose to be safe (33), and also judged our subjects carefully to exclude those at risk for developing hypercalcemia. During the study, only seven subjects reached a serum calcium value above $2.59 \mathrm{mmol} / \mathrm{l}$, which was our predefined hypercalcemia threshold. Two subjects, one given placebo, developed PHPT and, in retrospect, their baseline serum calcium and PTH levels, although not outside the preset limits for inclusion, indicated a disturbed calcium metabolism. Among the remainder, only one subject (in the DP group) had to be excluded due to serum calcium $>2.59 \mathrm{mmol} / \mathrm{l}$ at the re-examination. Most of the other adverse events were related to gastro-intestinal discomfort, most likely due to the calcium supplementation. Although a group of 449 subjects is small when considering the safety of the applied cholecalciferol doses, it does at least indicate that serious hypercalcemia is not a frequent consequence of administrating cholecalciferol doses in the range 20 000-40 000 IU weekly, at least not in overweight and obese subjects.

The present study has several limitations. We included subjects with BMI $>28 \mathrm{~kg} / \mathrm{m}^{2}$ and, therefore, our results do not necessarily apply to a slimmer population. In particular, the resulting serum 25(OH)D levels might have been higher, and possible side-effects more pronounced, in subjects with lower weight. Furthermore, there were slight differences in weight change between the three study groups, and we cannot exclude that these

Table 6 Characteristics at screening, time, and serum calcium level at event of hypercalcemia, retest values, and actions taken in subjects with serum calcium $>2.59 \mathrm{mmol} / \mathrm{l}$.

\begin{tabular}{|c|c|c|c|c|c|c|c|c|c|}
\hline \multirow[b]{2}{*}{ Gender } & \multicolumn{3}{|c|}{ Characteristics at screening } & \multirow[b]{2}{*}{ Group $^{a}$} & \multicolumn{2}{|c|}{ Event characteristics } & \multicolumn{2}{|c|}{ Retest values } & \multirow[b]{2}{*}{ Actions } \\
\hline & $\begin{array}{l}\text { Age } \\
\text { (years) }\end{array}$ & $\begin{array}{l}\text { S-calcium } \\
(\mathrm{mmol} / \mathrm{l})\end{array}$ & $\begin{array}{l}\text { S-PTH } \\
(\mathrm{pmol} / \mathrm{l})\end{array}$ & & Month & $\begin{array}{l}\text { S-calcium } \\
(\mathrm{mmol} / \mathrm{l})\end{array}$ & $\begin{array}{l}\text { S-calcium } \\
(\mathrm{mmol} / \mathrm{l})\end{array}$ & $\begin{array}{l}\text { S-PTH } \\
(\mathrm{pmol} / \mathrm{l})\end{array}$ & \\
\hline Female & 44 & 2.48 & 8.5 & DP & 6 & 2.72 & 2.58 & 9.5 & Surgery for PHPT \\
\hline Female & 63 & 2.48 & 7.8 & PP & 3 & 2.60 & 2.58 & 7.2 & Surgery for PHPT \\
\hline Female & 39 & 2.30 & 3.2 & DP & 6 & 2.62 & 2.60 & 1.6 & $\begin{array}{l}\text { Excluded. S-calcium } \\
\text { then normalized }\end{array}$ \\
\hline Male & 41 & 2.24 & 3.8 & DD & 9 & 2.61 & 2.38 & 2.1 & Continued in study \\
\hline Female & 64 & 2.46 & 3.9 & PP & 6 & 2.60 & 2.50 & 3.1 & Continued in study \\
\hline Female & 59 & 2.31 & 3.3 & DD & 3 & 2.61 & 2.39 & 2.7 & Continued in study \\
\hline Female & 46 & 2.29 & 6.4 & $\mathrm{DD}$ & 3 & 2.61 & 2.53 & 2.6 & Continued in study \\
\hline
\end{tabular}

aDD group: calcium $500 \mathrm{mg} /$ day + cholecalciferol $40000 \mathrm{IU} /$ week.

${ }^{\mathrm{b} D P}$ group: calcium $500 \mathrm{mg} / \mathrm{day}+$ cholecalciferol $20000 \mathrm{IU} /$ week.

CPP group: calcium $500 \mathrm{mg} /$ day + placebo. 
Table 7 Number of subjects experiencing adverse events during the study in relation to organ system affected.

\begin{tabular}{lccc}
\hline & \multicolumn{3}{c}{ Treatment group $^{\text {Organ system affected }}$} \\
\cline { 2 - 4 } & DD group $^{\mathrm{a}}$ & DP group $^{\mathrm{b}}$ & PP group $^{\mathrm{c}}$ \\
\hline Gastro-intestinal system & 27 & 24 & 24 \\
Respiratory system & 10 & 11 & 9 \\
Skin & 13 & 10 & 10 \\
Musculoskeletal system & 17 & 16 & 20 \\
Uro-genital system & 5 & 10 & 6 \\
Circulatory system & 10 & 14 & 10 \\
Nervous system & 7 & 17 & 10 \\
Endocrine system & 7 & 9 & 6 \\
Miscellaneous & 5 & 7 & 10 \\
Total & 101 & 118 & 105 \\
\hline
\end{tabular}

${ }^{\mathrm{a} C}$ Calcium $500 \mathrm{mg} /$ day + cholecalciferol $40000 \mathrm{IU} /$ week.

${ }^{\mathrm{b}}$ Calcium $500 \mathrm{mg} /$ day + cholecalciferol $20000 \mathrm{IU} /$ week.

${ }^{\mathrm{C}}$ Calcium $500 \mathrm{mg} /$ day + placebo.

${ }^{\mathrm{d}}$ Two subjects developed angina pectoris (one in the DD and one in the DP group).

differences would have been statistically significant in a cohort of similar size as in the Women's Health Initiative. In addition, there might be an effect of time of season when included in the study, that our study did not have the power to detect with statistical significance. The drop-out rate was $25.6 \%$, and most of the subjects who dropped out of the study gave no reason for their withdrawal, hence it is possible that not all side-effects were recorded. However, the drop-out rates were similar in all three groups. We used a new immunometric assay with reagents from Roche Diagnostics for the determination of serum 25(OH)D. Measurements of vitamin D in different laboratories are known to differ, and comparison of serum 25(OH)D levels with other studies must therefore be done with caution (34). We did not have a group that was given placebo preparations for both calcium and vitamin D. Although we find it unlikely, we cannot exclude that calcium supplementation may have masked an effect of vitamin D on weight.

On the other hand, our study has considerable strength. We included a large group of subjects, they were monitored carefully every third month, and they were given vitamin $\mathrm{D}$ in doses that should disclose potential beneficial effects.

We therefore find it safe to conclude that significant weight reduction in overweight and obese subjects is unlikely to occur in individuals supplemented with cholecalciferol doses as used in our study.

\section{Declaration of interest}

The authors declare that there is no conflict of interest that would prejudice the impartiality of this scientific work.

\section{Funding}

The present study was supported by a grant from The Northern Norway Regional Health Authority. Nycomed Norway supplied the calcium tablets used in the present study.

\section{Acknowledgements}

The superb assistance by the nurses at the Clinical Research Unit and by Inger Myrnes and Astrid Lindvall at the Department of Clinical Biochemistry, University Hospital of North Norway, is gratefully acknowledged. We are grateful for the generous supply of calcium tablets from Nycomed Norway. The invaluable assistance by Tom Wilsgaard at The Institute for Community Medicine, University of Tromsø, on some statistical issues is gratefully acknowledged.

\section{References}

1 Kopelman PG. Obesity as a medical problem. Nature $2000 \mathbf{4 0 4}$ 635-643.

2 Ravussin E \& Bogardus C. Energy balance and weight regulation: genetics versus environment. British Journal of Nutrition $2000 \mathbf{8 3}$ S17-S20.

3 Drent ML \& van der Veen EA. Endocrine aspects of obesity. Netherlands Journal of Medicine 199547 127-136.

4 Snijder MB, van Dam RM, Visser M, Deeg DJ, Dekker JM, Bouter LM, Seidel JC \& Lips P. Adiposity in relation to vitamin D status and parathyroid hormone levels: a population-based study in older men and women. Journal of Clinical Endocrinology and Metabolism $2005904119-4123$.

5 Zittermann A. Vitamin D in preventive medicine: are we ignoring the evidence? British Journal of Nutrition $200389552-572$.

6 Hyppönen E \& Power C. Vitamin D status and glucose homeostasis in the 1958 British birth cohort: the role of obesity. Diabetes Care $2006292244-2246$.

7 Arunabh S, Pollack S, Yeh J \& Aloia JF. Body fat content and 25-hydroxyvitamin D levels in healthy women. Journal of Clinical Endocrinology and Metabolism $2003 \mathbf{8 8} 157-161$.

8 Kamycheva E, Joakimsen RM \& Jorde R. Intakes of calcium and vitamin D predict body mass index in the population of Northern Norway. Journal of Nutrition 2003133 102-106.

9 Saleh F, Jorde R, Sundsfjord J, Haug E \& Figenschau Y. Causes of secondary hyperparathyroidism in a healthy population: the Tromsø study. Journal of Bone and Mineral Metabolism 200624 $58-64$.

10 Kamycheva E, Sundsfjord J \& Jorde R. Serum parathyroid hormone level is associated with body mass index. The 5 th Tromsø study. European Journal of Endocrinology 2004151 167-172.

$11 \mathrm{Ni} \mathrm{Z,} \mathrm{Smogorzewski} \mathrm{M} \mathrm{\&} \mathrm{Massry} \mathrm{SG.} \mathrm{Effects} \mathrm{of} \mathrm{parathyroid}$ hormone on cytosolic calcium of rat adipocytes. Endocrinology 1994135 1837-1844.

12 Xue B, Greenberg AG, Kraemer FB \& Zemel MB. Mechanism of intracellular calcium $\left(\left[\mathrm{Ca}^{2+}\right]_{\mathrm{i}}\right)$ inhibition of lipolysis in human adipocytes. FASEB Journal $2001152527-2529$.

13 Zemel MB, Shi H, Greer B, Dirienzo D \& Zemel PC. Regulation of adiposity by dietary calcium. FASEB Journal $2000141132-1138$.

14 McCarty MF \& Thomas CA. PTH excess may promote weight gain by impeding catecholamine-induced lipolysis-implications for the impact of calcium, vitamin D, and alcohol on body weight. Medical Hypotheses 200361 535-542.

15 Vieth R, Bischoff-Ferrari H, Boucher BJ, Dawson-Hughes B, Garland CF, Heaney RP, Holick MF, Hollis BW, Lamberg-Allardt C, McGrath J, Norman AW, Scragg R, Whiting SJ, Willett WC \& Zittermann A. The urgent need to recommend an intake of vitamin D that is effective. American Journal of Clinical Nutrition $2007 \mathbf{8 5}$ 649-650.

16 Bischoff-Ferrari HA, Giovannucci E, Willett WC, Dietrich T \& Dawson-Hughes B. Estimation of optimal serum concentrations of 25-hydroxyvitamin D for multiple health outcomes. American Journal of Clinical Nutrition $2006 \mathbf{8 4} 18-28$.

17 Beaulieu C, Kestekian R, Havrankova J \& Gascon-Barré M. Calcium is essential in normalizing intolerance to glucose that accompanies vitamin D depletion in vivo. Diabetes 199342 $35-43$. 
18 Andersen LF, Tomten H, Haggerty P, Løvø A \& Hustvedt B-E. Validation of energy intake estimated from a food frequency questionnnaire: a double labelled water study. European Journal of Clinical Nutrition 200357 279-284.

19 Ainsworth BE, Macera CA, Jones DA, Reis JP, Addy CL, Bowles HR \& Kohl HW III. Comparison of the 2001 BRFSS and the IPAQ physical activity questionnaires. Medicine and Science in Sports and Exercise 200638 1584-1592.

20 Ljunghall S, Lind L, Lithell H, Skarfors E, Selinus I, Sørensen OH \& Wide L. Treatment with one-alpha-hydroxycholecalciferol in middle-aged men with impaired glucose tolerance - a prospective randomized double-blind study. Acta Medica Scandinavica 1987 222 361-367.

21 Lind L, Pollare T, Hvarfner A, Lithell H, Sørensen OH \& Ljunghall S. Long-term treatment with active vitamin D (alphacalcidol) in middle-aged men with impaired glucose tolerance. Effects on insulin secretion and sensitivity, glucose tolerance and blood pressure. Diabetes Research 198911 141-147.

22 Nilas L \& Christiansen C. Treatment with vitamin D or its analogues does not change body weight or blood glucose level in postmenopausal women. International Journal of Obesity $1984 \mathbf{8}$ 407-411.

23 Trivedi DP, Doll R \& Khaw KT. Effect of four monthly oral vitamin D3 (cholecalciferol) supplementation on fractures and mortality in men and women living in the community: randomised double blind controlled trial. BMJ $2003 \mathbf{3 2 6} 469-475$.

24 Boon N, Hul GB, Sicard A, Kole E, Van Den Berg ER, Viguerie N, Langin D \& Saris WHM. The effects of increasing serum calcitriol on energy and fat metabolism and gene expression. Obesity 2006 14 1739-1746.

25 Caan B, Neuhouser M, Aragaki A, Lewis CB, Jackson R, LeBoff MS, Margolis KL, Powell L, Uwaifo G, Whitlock E, Wylie-Rosett J \&
LaCroix A. Calcium plus vitamin D supplementation and the risk of postmenopausal weight gain. Archives of Internal Medicine 2007 167 893-902.

26 Heaney RP, Davies KM \& Barger-Lux MJ. Calcium and weight: clinical studies. Journal of the American College of Nutrition 200221 $152 \mathrm{~S}-155 \mathrm{~S}$.

27 Zittermann A. Vitamin D and disease prevention with special reference to cardiovascular disease. Progress in Biophysics and Molecular Biology 200692 39-48.

28 Zemel MB. Regulation of adiposity and obesity risk by dietary calcium: mechanisms and implications. Journal of the American College of Nutrition 200221 146S-151S.

29 Shi H, Norman AW, Okamura WH, Sen A \& Zemel MB. 1 1 ,25Dihydroxyvitamin D3 modulates human adipocyte metabolism via nongenomic action. FASEB Journal $2001152751-2753$.

30 Holick MF. Vitamin D deficiency. New England Journal of Medicine $2007357266-281$.

31 Bischoff-Ferrari HA, Dietrich T, Orav EJ \& Dawson-Hughes B. Positive association between 25-hydroxy vitamin D levels and bone mineral density: a population-based study of younger and older adults. American Journal of Medicine 2004116 634-639.

32 Vieth R, Chan PC \& MacFarlane GD. Efficacy and safety of vitamin D3 intake exceeding the lowest observed adverse effect level. American Journal of Clinical Nutrition 200173 288-294.

33 Hathcock JN, Shao A, Vieth R \& Heaney R. Risk assessment for vitamin D. American Journal of Clinical Nutrition 200785 6-18.

34 Zerwekh JE. The measurement of vitamin D: analytical aspects. Annals of Clinical Biochemistry $200441272-281$.

Received 23 August 2008

Accepted 1 September 2008 